\title{
Effect of stage of lactation on the immune competence of goat mammary gland
}

\author{
M. Albenzio, ${ }^{1}$ A. Santillo, M. Caroprese, M. G. Ciliberti, R. Marino, and A. Sevi \\ Department of the Sciences of Agriculture, Food and Environment (SAFE), University of Foggia, Via Napoli, 25, 71100 Foggia, Italy
}

\begin{abstract}
The present research was undertaken to evaluate the effect of stage of lactation on immune competence of the goat mammary gland. The prevalence and etiology of intramammary infections and cytokine pattern were studied in individual caprine milk during lactation. A total of 1,200 caprine milk samples were collected during early, mid, and late lactation (less than $40 \mathrm{~d}$, from 110 to $130 \mathrm{~d}$, and more than $200 \mathrm{~d}$ in lactation, respectively) and analyzed for milk quality, bacterial cell load, and cytokine pattern. Contagious and environmental pathogens associated with intramammary infection were isolated from caprine milk. Nutritional components of caprine milk were affected by stage of lactation; fat, protein, casein, and whey protein increased along with lactation due to the lowest milk yield. Lactose content showed an opposite trend, with a reduced percentage passing from early to late lactation. The impaired rheological properties detected in early and late lactation milk were associated with a modification of milk quality. An impairment of microbial quality was detected at the end of lactation as a consequence of a major susceptibility of mammary gland to infections. The percentage of bacteriologically positive caprine milk samples was $44 \%$ throughout lactation. The incidence of bacteria associated with intramammary infection was different according to the stage of lactation with a major prevalence of Staphylococcus aureus, Enterobacteriaceae, Staphylococcus hyicus, and Streptococcus uberis in early lactation milk, Staphylococcus chromogenes, Streptococcus bovis, and Staphylococcus epidermidis in mid lactation, and Pseudomonas aeruginosa and Staphylococcus caprae in late lactation milk. The higher values of IL-1 $\beta$, tumor necrosis factor- $\alpha$, and IL-6 were ascribed to the major prevalence of Staphylococcus aureus at the beginning of lactation, whereas a higher level of IL-10 was detected in mid-lactation caprine milk and correlated with
\end{abstract}

Received October 14, 2015.

Accepted January 24, 2016.

${ }^{1}$ Corresponding author: m.albenzio@unifg.it
Staphylococcus chromogenes. Monitoring the cytokine pattern in milk helps to understand the immune status of the mammary gland, its ability to cope with bacteria, and the evolution of infections.

Key words: caprine milk, stage of lactation, intramammary infection, bacteria, cytokine

\section{INTRODUCTION}

In Europe and North America, the vast majority of goat milk is used to make dairy products (MorandFehr et al., 2004), and the yield and quality of cheese is crucially dependent on milk quality. Many factors can affect milk quality, such as genetics, nutrition, and husbandry; however, the single most important factor affecting cheese yield and quality in dairy ruminants, and in goats in particular, is the deleterious effect of subclinical mastitis (Silanikove et al., 2014).

Intramammary infections in sheep, goats, and dairy cattle are a major cause of economic loss to the dairy industry (Silanikove et al., 2014). Mastitic infections may be classified as either clinical or subclinical; the former is defined by the International Dairy Federation (IDF, 1987 ) as an udder inflammation characterized by visible abnormalities in the milk and udder and may be graded as mild, moderately, or seriously severe. The gold standard for the diagnosis of IMI in dairy species is bacterial culture. Although some overlap may exist between groups, mastitis pathogens may be broadly classified as contagious pathogens (Staphylococcus aureus, Streptococcus agalactiae), environmental pathogens (Escherichia coli, Pseudomonas aeruginosa, Streptococcus uberis, Staphylococcus chromogenes, Streptococcus bovis), and other CNS.

Subclinical mastitis is defined as an inflammation that is not visible and requires a diagnostic test for detection, such as measurement of SCC, and is the most prevalent form of the disease. Intramammary infection is the major cause of increased SCC in milk during lactation, causing infiltration of leukocytes from the blood, changing the proportion and distribution of leukocytes in milk (Leitner et al., 2012). In the inflammatory response, the mammary gland immune 
system is activated to eliminate the pathogen. This defense mechanism includes anatomical, cellular, and soluble factors that act in coordination and are crucial to the modulation of mammary gland resistance and susceptibility to infection. Neutrophil migration from the bloodstream to mammary gland tissue occurs as a response to proinflammatory cytokines, such as tumor necrosis factor- $\alpha$ (TNF- $\alpha)$ and IL-6. Several cytokines might also increase phagocytic bactericidal activity; bacteria are able to modulate cytokine production in the mammary gland immune system cells, which modifies the host innate immune response (Oviedo-Boyso et al., 2007).

To the best of our knowledge, no studies have been reported on the levels of cytokines in caprine milk during lactation. In the present research the effect of stage of lactation on immune competence of the goat mammary gland was characterized; in particular, the prevalence and etiology of IMI and the cytokine pattern were studied in individual caprine milk during lactation.

\section{MATERIALS AND METHODS}

\section{Experimental Design and Milk Sampling}

The experiment was conducted in 5 intensively managed dairy flocks of Garganica goat, located in Apulia region (southern Italy). The goats were between 2 and 5 lactations and were milked twice daily in a parlor using a pipeline milking machine; before milk collection, goats were carefully examined by a veterinarian to confirm the absence of any sign of clinical mastitis, such as fever, pain, or gland swelling, and a small quantity of milk was checked visually for signs of mastitis. Animal handling followed the recommendations of European Union directive 86/609/EEC concerning animal care. Goats were housed on straw litter; they grazed and were supplemented with hay and concentrate. Three sampling cycles were performed during early $(43 \pm 5$ DIM $)$, mid $(120 \pm 10$ DIM $)$, and late lactation $(205 \pm 12$ DIM). For each sampling cycle, 3 individual samples, representative of the entire milking, were collected in triplicate on 3 consecutive days. Animals involved in the study numbered 130 in early, 136 in mid, and 134 in late lactation; a total of 1,200 caprine milk samples were aseptically collected from both glands and analyzed for fat, total protein, and lactose (Milko Scan 133B; Foss Electric, Hillerød, Denmark), and for $\mathrm{pH}$ value (GLP 21 Crison, Spain). Total nitrogen, noncasein nitrogen (NCN), and NPN were determined by standard procedures using the Kjeldahl method (IDF, 1993). Casein nitrogen was calculated as the difference between total nitrogen protein and NCN; whey protein was calculated as the difference between
NCN and NPN. Somatic cell count was determined using a Fossomatic Minor (Foss Electric) according to the International Dairy Federation standard (IDF, 1995). Milk renneting characteristics (clotting time, rate of clot formation, and clot firmness after $30 \mathrm{~min}$ ) were measured using a Foss Electric Formagraph. Plasmin activity was determined according to the procedures described by Albenzio et al. (2015).

\section{Microbiological Analysis of Milk}

Mesophilic bacteria were detected using Plate Count Agar (Oxoid, Basingstoke, UK) incubated for $48 \mathrm{~h}$ at $32^{\circ} \mathrm{C}$. Total and fecal coliforms were detected using Violet Red Bile Agar (Oxoid) incubated for $24 \mathrm{~h}$ at 37 and $44^{\circ} \mathrm{C}$, respectively. Presumptive Escherichia coli were detected after $24 \mathrm{~h}$ of incubation on violet red bile agar with 4-methylumbelliferyl-(-D-glucuronide) at $44.5 \pm 0.5^{\circ} \mathrm{C}(\mathrm{SD})$. Staphylococci were detected after $48 \mathrm{~h}$ incubation on Baird Parker agar (Oxoid) supplemented with egg yolk tellurite emulsion at $37^{\circ} \mathrm{C}$ and subsequently identified at species level using the APISTAPH System (Biomerieux, Marcy l'Etoile, France). Enterococci were determined on Slanetz-Bartley medium (Biolife, Milan, Italy) and pyogenic streptococci on modified Edwards' esculin medium (Oxoid) at $37^{\circ} \mathrm{C}$ after 24 to $48 \mathrm{~h}$ of incubation. Streptococcal isolates were then speciated using the API 20 Strep System (Biomerieux). Pseudomonas spp. were determined using Pseudomonas-selective agar (Oxoid); Pseudomonas aeruginosa was detected after $3 \mathrm{~d}$ of incubation on Pseudomonas agar F and Pseudomonas agar P (Oxoid) at 32 to $37^{\circ} \mathrm{C}$. Samples were considered bacteriologically positive when at least $10^{3} \mathrm{cfu} / \mathrm{mL}$ of the same type were isolated (Watkins et al., 1991). Goats whose udders were without clinical abnormalities and whose milk was bacteriologically positive were considered to have IMI and defined as infected. Pathogens isolated were classified as environmental (E. coli, P. aeruginosa), CNS (Staph. chromogenes, Staphylococcus xylosus, Staphylococcus lentus, Staph. epidermidis, Staphylococcus capitis, Staphylococcus warneri, Staphylococcus auricularis, Staphylococcus saprophyticus, Staphylococcus hominis, Staphylococcus simulans, Staph. caprae, Staphylococcus sciuri), streptococci (Enterococcus avium, Aerococcus viridians, Streptococcus suis, Enterococcus durans, Strep. uberis), and Enterobacteriaceae. In every case, E. coli, the main environmental pathogen, was isolated. If an organism was isolated in pure growth, or was the predominant growth, the organism was considered to be the cause of IMI. A sample was called a mix growth if growth of 2 known IMI pathogens were detected. A sample was labeled contaminated if more than 3 organisms were isolated (Bradley and Green, 2000). 


\section{Determination of Cytokines in Caprine Milk}

All milk samples were centrifuged at $2,000 \times g$ for $30 \mathrm{~min}$ at $4^{\circ} \mathrm{C}$; the fatty fraction was removed and the whey was collected for IL-1 $\beta$, IL-6, IL-10, TNF- $\alpha$, and IL- 8 analysis. The detection of IL- $1 \beta$ and IL- 6 in whey were determined by capture ELISA performed on 96-well microtiter plates according to Caroprese et al. (2006). Whey samples were read against the standard curves, obtained using a scalar dilution of recombinant bovine IL-1 $\beta$ and IL-6 $[\mathrm{y}=(0.21-1.47) /[1+$ $\left.(\mathrm{x} / 3.44)^{1.04}\right]+1.47, \mathrm{R}^{2}=99 \%$ for IL-1 $\beta$; and $\mathrm{y}=(0.1$ $-1.84) /\left[1+(\mathrm{x} / 4.17+004)^{1.21}\right]+1.84, \mathrm{R}^{2}=99.9 \%$ for IL-6, respectively; Kingfisher Biotech Inc., St. Paul, $\mathrm{MN}]$. Data were expressed as nanograms per milliliter of IL-1 $\beta$ and of IL-6. Intra- and interassay coefficients of variations for IL- $1 \beta$ and IL- 6 were 6.3 and $8.2 \%$ and 6.8 and $8.9 \%$, respectively.

Interleukin-10 production in whey was determined using a pair of bovine-specific monoclonal antibodies against IL-10 (Serotec, Oxford, UK) in a sandwich capture ELISA described in detail by Kwong et al. (2002). The standard curve obtained for IL-10 was $\mathrm{y}=$ $(0.043-2.91) /\left[1+(\mathrm{x} / 81.8)^{0.798}\right]+2.91\left(\mathrm{R}^{2}=99,9 \%\right)$ and was made up by bovine recombinant proteins purchased by Kingfisher Biotech Inc. Intra- and interassay coefficients of variation for IL-10 were 6.5 and $7.6 \%$, respectively.

The detection of TNF- $\alpha$ in whey was determined by sandwich ELISA performed on 96-well microtiter plates according to Hope et al. (2003) using bovine monoclonal antibody specific for TNF- $\alpha$ (Serotec Ltd.). Data were expressed as nanograms per milliliter of TNF- $\alpha$, the standard curve $\left(\mathrm{y}=0.000216-0.119 ; \mathrm{R}^{2}=97.7 \%\right)$ was made up by bovine TNF- $\alpha$ recombinant protein (Serotec Ltd.). Intra- and interassay coefficients of variation for TNF- $\alpha$ were 5.2 and $7.7 \%$, respectively.

The detection of ovine IL- 8 was determined with a standard sandwich ELISA performed on 96-well microtiter plates according to Caswell et al. (1998) and modified by Herndon et al. (2010) using monoclonal anti-ovine IL-8 antibody (Serotec Ltd.) in coating buffer carbonate ( $\mathrm{pH} 9.6)$, diluted 1:5,000 (100 $\mu \mathrm{L} /$ well). Nonspecific bindings were blocked with bovine Na-caseinate (1\% in PBS, $\mathrm{pH} 7.2$ ) at $37^{\circ} \mathrm{C}$ for $45 \mathrm{~min}$. Ovine IL-8 evaluation was a qualitative assay, and the data were expressed in optical density. Intra- and interassay coefficients of variation for IL- 8 were 7.2 and $9.7 \%$, respectively.

\section{Statistical Analysis}

All variables were tested for normal distribution using the Shapiro-Wilk test (Shapiro and Wilk, 1965).
Milk SCC and microbial cell loads were transformed into logarithmic form to normalize their frequency distribution before performing statistical analysis. Data were processed using ANOVA for repeated measures (SAS Institute, 2011). The variation due to the fixed effect of stage of lactation in milk composition, microbial cell load, and cytokine was tested. Replication within treatment was used as the error term. Where significant effects were found $(P<0.05)$, the Student's $t$-test was used to locate significant differences between means. Linear simple correlation between cytokines and identified microorganism via stage of lactation were also studied.

\section{RESULTS AND DISCUSSION}

\section{Caprine Milk Features}

Milk yield, SCC, pH, chemical composition, and technological parameters of caprine milk during lactation are presented in Table 1. Milk yield significantly decreased $(P<0.05)$ in late lactation as a result of the impairment of mammary gland efficiency in the milk synthesis. The SCC increased $(P<0.001)$ with advancing lactation, reaching the threshold of $6 \log _{10} \mathrm{SCC} /$ $\mathrm{mL}$ at the end of lactation. Recently, it was reported a threshold of 700,000 cells/mL for changes in leukocyte distribution related to the immune status of the goat mammary gland (Albenzio et al., 2015). In the current study, nutritional components of caprine milk were affected by stage of lactation; fat, protein, casein, and whey protein increased along with lactation due to the lowest milk yield. Lactose content showed an opposite trend, with a reduced percentage passing from early to late lactation; accordingly, Das and Singh (2000) found a lactose content of about $4 \%$ in late-lactation milk. The reduced secretion of lactose was related to the activation of the plasmin-plasminogen system that physiologically occurs in late lactation; the liberation of $\beta$-CN fragments are regulatory elements which block $\mathrm{K}^{+}$-channels influencing the release of lactose into the milk (Leitner et al., 2011). The reduced output of lactose could have led to an increase of ions involved in the osmotic equilibrium that may be responsible for the highest value of $\mathrm{pH}$ at the end of lactation. In bovine milk, an increase was found in milk $\mathrm{pH}$ passing from early to late lactation (Le Roux et al., 2003).

The present results highlighted that milk plasmin activity increased $(P<0.001)$ significantly in caprine along with lactation, being $7.58,10.30$, and $18.10 \pm 1.04$ $\mathrm{U} / \mathrm{mL}$ in early, mid, and late lactation, respectively. Clotting time was the lowest, whereas clot firmness was the highest in mid-lactation milk, displaying a greater coagulating performance as an outcome of caprine milk 
Table 1. Milk yield, SCC, pH, chemical composition, and technological properties in individual caprine milk during lactation

\begin{tabular}{lccccc}
\hline & \multicolumn{3}{c}{ Stage of lactation } & & \\
\cline { 2 - 4 } Item & Early & Mid & Late & SEM & $P$-value \\
\hline Milk yield, kg/d & $4.93^{\mathrm{b}}$ & $4.43^{\mathrm{b}}$ & $3.04^{\mathrm{a}}$ & 0.22 & $*$ \\
SCC, $\log _{10}$ cells $/ \mathrm{mL}$ & $5.60^{\mathrm{a}}$ & $5.89^{\mathrm{b}}$ & $6.11^{\mathrm{c}}$ & 0.04 & $* * *$ \\
$\mathrm{pH}$ & $6.75^{\mathrm{b}}$ & $6.65^{\mathrm{a}}$ & $6.9^{\mathrm{c}}$ & 0.02 & $* * *$ \\
Fat, $\%$ & $4.60^{\mathrm{a}}$ & $5.75^{\mathrm{b}}$ & $6.78^{\mathrm{c}}$ & 0.21 & $* * *$ \\
Protein, \% & $3.52^{\mathrm{a}}$ & $3.82^{\mathrm{b}}$ & $4.95^{\mathrm{c}}$ & 0.05 & $* * *$ \\
Lactose, \% & $4.50^{\mathrm{c}}$ & $4.26^{\mathrm{b}}$ & $4.08^{\mathrm{a}}$ & 0.05 & $* * *$ \\
Casein, $\%$ & $2.39^{\mathrm{a}}$ & $2.59^{\mathrm{b}}$ & $2.6^{\mathrm{b}}$ & 0.05 & $* * *$ \\
Whey protein, \% & $0.95^{\mathrm{a}}$ & $1.09^{\mathrm{b}}$ & $1.17^{\mathrm{c}}$ & 0.02 & $* * *$ \\
Clotting time, min & $13.26^{\mathrm{b}}$ & $8.42^{\mathrm{a}}$ & $11.35^{\mathrm{b}}$ & 0.85 & $*$ \\
Clot firmness 30 min, mm & $27.01^{\mathrm{a}}$ & $39.92^{\mathrm{b}}$ & $22.54^{\mathrm{a}}$ & 2.50 & $*$ \\
\hline
\end{tabular}

${ }^{*} P<0.05,{ }^{* * *} P<0.001$.

features. In early-lactation milk the impaired rheological properties could be related to the minor efficiency of the mammary gland to secrete milk components, especially fat and protein, whereas in late-lactation milk the highest plasmin activity could be responsible for the disruption of the casein substrates influencing the clotting characteristics of milk.

The sharp increase in SCC at the end of lactation may be interpreted as an adaptive response to the involution of the mammary gland; this response aids the clearance of existing bacterial infections and prevents the transmission of infection from one lactation to the next (Leitner et al., 2011). It is worth noting that the main physiological factor involved in the variation of $\mathrm{SCC}$ in goats is the stage of lactation (Gomes et al., 2006).

\section{Prevalence and Etiology of IMI in Caprine Milk}

The cell load of the principal microbial groups in caprine milk during lactation is presented in Table 2 . Mesophilic bacteria, streptococci, and Pseudomonas spp. cell loads were affected by stage of lactation. Mesophilic bacteria were higher $(P<0.001)$ in mid lactation, whereas Pseudomonas spp. were higher $(P<$ 0.001) in late lactation; Streptococcus spp. were higher
$(P<0.01)$ in mid- and late-lactation milk. Microbial cell loads evidenced an impairment of microbial quality at the end of lactation as a consequence of a major susceptibility of the mammary gland to infections; however, few studies have been conducted on microbial pattern in caprine milk. In a survey study, Muehlherr et al. (2003) reported that $77 \%$ of caprine bulk milk resulted below the standard plate count limits fixed by the European Union regulations (92/46/EEC). Furthermore, Morgan et al. (2003) reported an average bacterial count ranging from $10^{4}$ to $10^{7} \mathrm{cfu} / \mathrm{mL}$ in small and medium enterprises of Greece, France, and Portugal.

The prevalence and etiology of IMI in caprine milk samples during lactation is presented in Table 3. Limited data about the incidence of IMI in small ruminants are available; the prevalence of subclinical mastitis in small ruminants has been estimated at 5 to $30 \%$ or even higher (Contreras et al., 2007). In the current study, about $44 \%$ of caprine milk samples analyzed throughout lactation turned out to be bacteriologically positive; in particular, the distribution of positive samples according to the lactation stage was 40,50 , and $43 \%$ in early, mid, and late lactation, respectively. The incidence of Staph. aureus varied during lactation with a major percentage of cases isolated in early lactation then moving

Table 2. Cell load of the principal microbial groups in individual caprine milk during lactation

\begin{tabular}{llllll}
\hline & \multicolumn{3}{c}{ Stage of lactation } & & \\
\cline { 2 - 3 } Item, $\log _{10}$ cfu/mL & Early & Mid & Late & \multirow{2}{*}{ SEM } & $P$-value \\
\hline Mesophilic bacteria cell count & $5.55^{\mathrm{a}}$ & $6.72^{\mathrm{b}}$ & $5.35^{\mathrm{a}}$ & 0.23 & $* * *$ \\
Total coliform cell count & 3.69 & 4.72 & 4.21 & 0.27 & NS \\
Fecal coliform cell count & 1.63 & 1.04 & 1.63 & 0.19 & NS \\
Staphylococci cell count & 3.22 & 3.99 & 3.88 & 0.25 & NS \\
Streptococci cell count & $2.52^{\mathrm{a}}$ & $3.94^{\mathrm{b}}$ & $3.61^{\mathrm{b}}$ & 0.24 & $* *$ \\
Pseudomonas spp. & $4.1^{\mathrm{a}}$ & $4.2^{\mathrm{a}}$ & $4.75^{\mathrm{b}}$ & 0.1 & $* * *$ \\
\hline$* * P<0.01, * * * P<0.001$ & & & & &
\end{tabular}

** $P<0.01,{ }^{* * *} P<0.001$. 
to a lower percentage with the advancement of lactation. The mammary gland could be more susceptible to pathogens invasion at the onset of lactation than in the later stages due to both a reduced immune response in the postpartum period and the onset of machine milking. Higher rates of incidence of IMI are observed at the beginning of machine milking (Bergonier et al., 2003); indeed, machine milking parameters and settings can have large effects on teat and thickness changes and efficiency of milk removal in small ruminants (Marnet and McKusick, 2001). Furthermore, during the period following parturition, the decrease in neutrophils activity is associated with a higher incidence of mastitis (Sordillo and Streicher, 2002).

Pseudomonas aeruginosa was detected only in latelactation caprine milk samples; this microorganism is regarded as an environmental bacterium that could have found favorable conditions for its growth in the latest phase of lactation. Coagulase-negative staphylococci reached $38 \%$ in mid lactation, $34 \%$ in late lactation, and $28 \%$ in early lactation. However, within this microbial group the most represented CNS were different according to the stage of lactation; in particular, Staph. chromogenes and Staph. epidermidis were over the threshold of $20 \%$ in mid lactation, Staph. caprae, Staph. capitis, and Staph. hominis were the most frequently isolated in late lactation, and Staph. hyicus was isolated in $38 \%$ and Staph. caprae in $15 \%$ of CNS in early lactation. Cases of bacteriologically positive samples for Streptococcus species increased along with lactation, reaching over $40 \%$ of the total in late lactation. Within Streptococcus species, a prevalence of about 30\% was found for Strep. uberis in both early and late lactation, whereas Strep. bovis represented over $20 \%$ of the isolates in mid-lactation milk. Enterobacteriaceae was the prevalent group of the bacteriologically positive samples in early lactation, though the numbers halved in subsequent stages of lactation.

Coagulase-negative staphylococci are the most prevalent agents in subclinical mastitis in small ruminants; in goats, Staph. caprae is one of the most prevalent species, followed by Staph. chromogenes and Staph. simulans (Bergonier et al. 2003). Enterobacteriaceae have classically been classified as opportunistic environmental pathogens capable of entering the udder and causing a transient infection occasionally accompanied by severe systemic disease. In dairy cows, a significant number of intramammary enterobacterial infections are acquired during the dry period, and udders that acquire infection are more likely to develop mastitis in the subsequent lactation (Bradley and Green, 2000).

Cytokine pattern in caprine milk samples during lactation is presented in Table 4. Interleukin-1 $\beta$, TNF- $\alpha$, IL-10, and IL-6 were affected by stage of lactation. In
Table 3. Prevalence (\%) and etiology of IMI in caprine milk samples during lactation

\begin{tabular}{lccc}
\hline & \multicolumn{3}{c}{ Stage of lactation } \\
\cline { 2 - 4 } Item & Early & Mid & Late \\
\hline Bacteriological positive samples & 40 & 50 & 43 \\
Pseudomonas aeruginosa & - & - & 7 \\
Staphylococcus aureus & 28 & 13 & 6 \\
CNS & 28 & 38 & 34 \\
Staphylococcus hyicus & 38 & 3 & 9 \\
Staphylococcus simulans & 12 & 5 & - \\
Staphylococcus caprae & 15 & 2 & 22 \\
Staphylococcus capitis & 4 & 2 & 16 \\
Staphylococcus cohnii ssp. cohnii & 8 & - & 12 \\
Staphylococcus epidermidis & 11 & 20 & 9 \\
Staphylococcus chromogenes & 4 & 35 & 5 \\
Staphylococcus warneri & 4 & 3 & 3 \\
Staphylococcus haemolyticus & 4 & 4 & - \\
Staphylococcus carnosus & - & 3 & - \\
Staphylococcus lugdunensis & - & - & 6 \\
Staphylococcus sciuri & - & - & 3 \\
Staphylococcus hominis & - & - & 15 \\
Streptococcus spp. & 23 & 36 & 41 \\
Aerococcus viridans & 10 & 9 & - \\
Streptococcus bovis I & - & 22 & 5 \\
Streptococcus bovis II & - & 6 & 12 \\
Streptococcus anginosus & - & 9 & 5 \\
Streptococcus agalactiae & - & 7 & - \\
Streptococcus uberis & 30 & 16 & 33 \\
Globicatella sanguinis & - & - & 11 \\
Enterobacteriaceae & 60 & 31 & 34 \\
\hline
\end{tabular}

general IL-1 $\beta$, TNF- $\alpha$, and IL- 6 were the highest in early-lactation milk, and TNF- $\alpha$ in particular showed an intermediate level in late-lactation milk. Interleukin-10 showed higher level in caprine milk during mid lactation.

To the best of our knowledge, no studies have reported levels of cytokines in caprine milk during lactation. The onset of lactation as well as the involution of mammary gland represents a challenge for the immune system of mammary gland. Monitoring cytokine pattern could help to understand the immune status of mammary gland and its ability to cope with pathogens or environmental bacterial infections. Some bacteria are able to modulate cytokines production in the mammary gland immune system cells, such as IL- $1 \beta$ and TNF- $\alpha$, which increase phagocytic bactericidal activity (Oviedo-Boyso et al., 2007). The higher values of IL-1 $\beta$ may be ascribed to the major prevalence of Staph. aureus. It has been reported that this cytokine is involved in the early stage of infections caused by Staph. aureus (Yamanaka et al., 2000). In the current study on caprine milk, a positive correlation $(\mathrm{r}=0.48, P<0.05)$ was found between IL-1 $\beta$ and Staph. hominis in late-lactation milk when the microorganism was identified. Interleukin-1 $\beta$ is produced by monocytes or macrophages and epithelial cells, whereas TNF- $\alpha$ is produced by macrophages, neutrophils, and epithelial cells, as these cytokines are 
Table 4. Interleukin-1 $\beta$, tumor necrosis factor- $\alpha$ (TNF- $\alpha$ ), IL-8, IL-10, and IL-6 in individual caprine milk during lactation

\begin{tabular}{|c|c|c|c|c|c|}
\hline \multirow[b]{2}{*}{ Item } & \multicolumn{3}{|c|}{ Stage of lactation } & \multirow[b]{2}{*}{ SEM } & \multirow[b]{2}{*}{$P$-value } \\
\hline & Early & Mid & Late & & \\
\hline IL-1 $\beta, \mathrm{ng} / \mathrm{mL}$ & $4.57^{\mathrm{b}}$ & $2.57^{\mathrm{a}}$ & $1.59^{\mathrm{a}}$ & 0.35 & $* * *$ \\
\hline $\mathrm{TNF}-\alpha, \mathrm{ng} / \mathrm{mL}$ & $2.52^{\mathrm{c}}$ & $2.23^{\mathrm{a}}$ & $2.31^{\mathrm{b}}$ & 0.04 & $*$ \\
\hline IL-8, optical density & 0.36 & 0.38 & 0.35 & 0.02 & NS \\
\hline $\mathrm{IL}-10, \mathrm{ng} / \mathrm{mL}$ & $3.03^{\mathrm{a}}$ & $3.90^{\mathrm{b}}$ & $2.58^{\mathrm{a}}$ & 0.30 & $*$ \\
\hline IL-6, ng/mL & $10.49^{\mathrm{b}}$ & $3.86^{\mathrm{a}}$ & $3.81^{\mathrm{a}}$ & 0.32 & $*$ \\
\hline
\end{tabular}

${ }^{*} P<0.05,{ }^{* * *} P<0.001$

involved in the initial phase of bacterial infection. Some authors (Oviedo-Boyso et al., 2007) also reported that TNF- $\alpha$ increased in subclinical infection of Staph. aureus; furthermore, in bovine mammary glands exposed to Strep. uberis they found an increase of IL-1 $\beta$ and TNF- $\alpha$. Interleukin-6 is a pleiotropic cytokine with both pro- and anti-inflammatory properties; its expression is induced by bacteria and viruses as well as by cytokines, such as IL-1 $\beta$ and TNF- $\alpha$ (van der Poll and van Deventer, 1998). Increased concentrations of IL-6 protein have been detected in the milk and blood of cows with naturally acquired and experimentally induced mastitis (Ohtsuka et al., 2001; Dernfalk et al., 2007). Interleukin-10 could play a central role in limiting inflammation and influencing the nature of the adaptive immune response to infection. In our study, IL-10 was found positively correlated with Staph. hyicus $(\mathrm{r}=0.63, P<0.01)$ and Staph. simulans $(\mathrm{r}=0.80$, $P<0.001)$ in early-lactation milk when these microorganisms displayed higher percentages within the early stages of lactation. Furthermore, Staph. hyicus was the most prevalent microorganism among CNS in early lactation milk. Interleukin-10 induces the upregulation of IL-1 $\beta$ receptor antagonist and soluble TNF receptors, which results in an impairment to exert their effects. Interleukin-10 production is considered beneficial to limit the secretion of proinflammatory cytokines and protect tissues from injury (Zhong et al., 2006). In the current study, a positive correlation was found between Staph. chromogenes and both TNF- $\alpha(\mathrm{r}=0.52, P<$ $0.01)$ and IL-10 $(\mathrm{r}=0.60, P<0.01)$ in mid-lactation milk when this microorganism was the most prevalent among CNS.

\section{CONCLUSIONS}

The percentage of bacteriologically positive caprine milk samples was $44 \%$ throughout lactation. The incidence of bacteria associated with IMI was different according to the stage of lactation, with a major prevalence of Staph. aureus, Enterobacteriaceae, Staph. hyicus, and Strep. uberis in early-lactation milk, of Staph. chromogenes, Strep. bovis, and Staph. epidermidis in mid-lactation milk, and of P. aeruginosa and Staph. caprae in late-lactation milk. The onset of lactation as well as the involution of mammary gland represent a challenge for the immune system of the mammary gland. The incidence of Staph. aureus varied during lactation, with a major percentage of cases isolated in early lactation leading to higher levels of IL- $1 \beta$, TNF- $\alpha$, and IL-6. The higher levels of IL-10 in mid lactation exemplified the role of this regulatory cytokine in limiting inflammation as well as in the control of the adaptive immune response to bacterial exposure of the mammary gland. Monitoring the cytokine pattern in milk helps to understand the immune status of the mammary gland, its ability to cope with bacteria, and the evolution of infections.

\section{ACKNOWLEDGMENTS}

The present work was partly supported by the Italian Ministry of Agricultural, Food and Forestry Policies (MIPAAF), Rome, Italy. The authors are grateful to the founders of the project LAIFF "Reti di laboratorio per l'innovazione nel campo degli alimenti funzionali," cod. no. 47, cofinanced by the Apulia Region "Reti di Laboratori Pubblici di Ricerca" (PO Puglia FESR 2007-2013, Asse I, Linea 1.2), Italy.

\section{REFERENCES}

Albenzio, M., A. Santillo, A. L. Kelly, M. Caroprese, R. Marino, and A. Sevi. 2015. Activities of indigenous proteolytic enzymes in caprine milk of different somatic cell counts. J. Dairy Sci. 98:7587-7594.

Bergonier, D., R. De Cremoux, R. Rupp, G. Lagriffoul, and X. Berthelot. 2003. Mastitis of dairy small ruminants. Vet. Res. 34:689-716.

Bradley, A. J., and M. J. Green. 2000. A study of the incidence and significance of intramammary enterobacterial infections acquired during the dry period. J. Dairy Sci. 83:1957-1965.

Caroprese, M., M. Albenzio, G. Annicchiarico, and A. Sevi. 2006. Changes occurring in immune responsiveness of single- and twinbearing Comisana ewes the transition period. J. Dairy Sci. 89:562568.

Caswell, J. L., D. M. Middleton, S. D. Sorden, and J. R. Gordon 1998. Expression of the neutrophil chemoattractant interleukin- 8 in the lesions of bovine pneumonic pasteurellosis. Vet. Pathol. $35: 124-131$ 
Contreras, A., D. Sierra, A. Sánchez, J. C. Corrales, J. C. Marco, M. J. Paape, and C. Gonzalo. 2007. Mastitis in small ruminants. Small Rumin. Res. 68:145-153.

Das, M., and M. Singh. 2000. Variation in blood leucocytes, somatic cell count, yield and composition of milk of crossbred goats. Small Rumin. Res. 35:169-174.

Dernfalk, J., K. Persson Waller, and A. Johannisson. 2007. The xMAP technique can be used for detection of the inflammatory cytokines IL-1beta, IL-6 and TNF-alpha in bovine samples. Vet. Immunol. Immunopathol. 118:40-49.

Gomes, V., A. M. M. Paiva Della Libera, M. Paiva, K. Medici Madureira, and W. Pereira Araújo. 2006. Effect of the stage of lactation on somatic cell counts in healthy goats (Caprae hircus) breed in Brazil. Small Rumin. Res. 64:30-34.

Herndon, C. N., W. J. Foreyt, and S. Srikumaran. 2010. Differential expression of interleukin- 8 by polymorphonuclear leukocytes of two closely related species, Ovis canadensis and Ovis aries, in response to Mannheimia haemolytica infection. Infect. Immun. $78: 3578-3584$.

Hope, J. C., A. O. Whelan, R. G. Hewinson, M. Vordermeier, and C. J. Howard. 2003. Maturation of bovine dentritic cells by lipopeptides. Vet. Immunol. Immunopathol. 95:21-31.

IDF. 1987. Bovine mastitis. Definition and guidelines terminology. FIL-IDF Standard No 211. International Dairy Federation (IDF), Brussels, Belgium.

IDF. 1993. Determination of nitrogen content. FIL-IDF Standard no. 20B. IDF, Brussels, Belgium.

IDF. 1995. Enumeration of somatic cells. FIL-IDF Standard No 148A. IDF, Brussels, Belgium.

Kwong, L. S., J. C. Hope, M. L. Thom, P. Sopp, S. Duggan, G. P. Bembridge, and C. J. Howard. 2002. Development of an ELISA for bovine IL-10. Vet. Immunol. Immunopathol. 85:213-223.

Le Roux, Y., F. Laurent, and F. Moussaoui. 2003. Polymorphonuclear proteolytic activity and milk composition change. Vet. Res. 34:629-645.

Leitner, G., U. Merin, O. Krifucks, S. Blum, A. L. Rivas, and N. Silanikove. 2012. Effects of intra-mammary bacterial infection with coagulase negative staphylococci and stage of lactation on shedding of epithelial cells and infiltration of leukocytes into milk: Comparison among cows, goats, and sheep. Vet. Immunol. Immunopathol. $147: 202-210$

Leitner, G., U. Merin, and N. Silanikove. 2011. Effects of glandular bacterial infection and stage of lactation on milk clotting parameters: comparison among cows, goats, and sheep. Int. Dairy J. $21: 279-285$.

Marnet, P. G., and B. C. McKusick. 2001. Regulation of milk ejection and milkability in small ruminants. Livest. Prod. Sci. 70:125-133.
Morand-Fehr, P., J. P. Boutonnet, C. Devendra, J. P. Dubeuf, G. F. W. Haenlein, P. Holst, L. Mowlem, and J. Capote. 2004. Strategy for goat farming in the 21st century. Small Rumin. Res. 51:175183.

Morgan, F., T. Massouras, M. Barbosa, L. Roseiro, F. Ravasco, I. Kandarakis, V. Bonnin, M. Fistakoris, E. Anifantakis, G. Jaubert, and K. Raynal-Ljutovac. 2003. Characteristics of goat milk collected from small and medium enterprises in Greece, Portugal, and France. Small Rumin. Res. 47:39-49.

Muehlherr, J. E., C. Zweifel, S. Corti, J. E. Blanco, and R. Stephan. 2003. Microbiological quality of raw goat's and ewe's bulk-tank milk in Switzerland. J. Dairy Sci. 86:3849-3856.

Ohtsuka, H., K. Kudo, K. Mori, F. Nagai, A. Hatsugaya, M. Tajima, K. Tamura, F. Hoshi, and S. Kawamura. 2001. Acute phase response in naturally occurring coliform mastitis. J. Vet. Med. Sci. 63:675-678.

Oviedo-Boyso, J., J. J. Valdez-Alarcón, M. Cajero-Juárez, A. OchoaZarzosa, J. E. López-Meza, A. Bravo-Patiño, and V. M. Baizabal-Aguirre. 2007. Innate immune response of bovine mammary gland to pathogenic bacteria responsible for mastitis. J. Infect. 54:399-409.

SAS Institute. 2011. SAS User's Guide. Version 9.2 SAS Institute Inc., Cary, NC

Shapiro, S. S., and M. Wilk. 1965. An analysis of variance test for normality. Biometrika 52:591-601.

Silanikove, N., U. Merin, and G. Leitner. 2014. On effects of subclinical mastitis and stage of lactation on milk quality in goats. Small Rumin. Res. 122:76-82.

Sordillo, L. M., and K. L. Streicher. 2002. Mammary gland immunity and mastitis susceptibility. J. Mamm. Gland Biol. Neoplasia $7: 135-146$

van der Poll, T., and S. J. van Deventer. 1998. The role of interleukin 6 in endotoxin-induced inflammatory responses. Prog. Clin. Biol. Res. 397:365-377.

Watkins, G. H., A. R. Burriel, and J. E. T. Jones. 1991. A field investigation of subclinical mastitis in sheep in southern England. Br. Vet. J. 147:413-420.

Yamanaka, H., K. Hisaeda, K. Hagiwara, R. Kirisawa, and H. Iwai. 2000. ELISA for bovine interleukin 1 receptor antagonist and its application to mastitic sera and whey. J. Vet. Med. Sci. 62:661664.

Zhong, J., I. Deaciuc, R. Burikhanov, and W. de Villiers. 2006. Lipopolysaccharide-induced liver apoptosis is increased in interleukin-10 knockout mice. Biochim. Biophys. Acta 1762:468-477. 